\title{
With or Without You: Suspension, Expulsion, and the Limits of Membership Sanctions in Regional Human Rights Regimes
}

\author{
Silvia Steininger* \\ Research Fellow, Max Planck Institute for Comparative Public Law and \\ International Law, Heidelberg, Germany \\ steininger@mpil.de
}

Abstract

Keywords

I. Introduction: How to Push Back Against the Pushback? 534

II. The Role of Membership Sanctions $\quad 537$

1. How Sanction? Instruments, Rules, and Veto Points 537

2. Why Sanction? The Need for Carrots and Sticks in Times of Backlash 541

III. Membership Sanctions in Regional Human Rights Regimes 544

1. The Law and Practice of Expulsion 545

2. The Law and Practice of Suspension 548

IV. Membership Sanctions in Times of Backlash: Sanctioning Russia 553

1. The Credential Procedure as an Instrument of Irregular Suspension 555

2. The PACE and the Credentials of the Russian Delegation 558

3. The Development of the Complementary Joint Procedure (2019) 561

V. Conclusion: The Limits of Membership Sanctions 565

\begin{abstract}
In the course of the so-called backlash against human rights courts, the regional human rights regimes in Europe, the Americas, and Africa are hardpressed to respond to states which attempt to undermine or abolish them. This raises the question of whether they should impose membership sanctions, i. e. sanctions that regulate the participation of state parties in international institutions. All three regimes contain the legal possibility for membership sanctions such as expulsion or suspension, however, concerned for their effect upon the population and civil society, they have been reluctant to apply

* LL.M., M. A. For helpful comments and remarks, I am indebted to the Dienstagsrunde of Armin von Bogdandy, Kanstantsin Dzehtsiarou, Rainer Grote, Anne Peters, Jörg Polakiewicz, René Urueña, Vassilis Tzelevekos, the anonymous peer reviewers as well as the participants of the ECPR Joint Session 'Judicial Authority Under Pressure' at the University of Louvain Mons (8-12 April 2019) and the workshop 'Loyal Co-operation within the System of the European Convention on Human Rights' at the University Liverpool (10-11 May 2019).
\end{abstract}


membership sanctions. This article investigates whether membership sanctions are an effective and legitimate instrument to respond to state backlash in the current crisis. It adopts a comparative regional approach for analysing the law and practice of expulsion and suspension in the European, InterAmerican, and African human rights regimes, before focusing on the debate on irregular sanctioning procedures against Russia at the Council of Europe.

\section{Keywords}

Human rights - backlash - sanctions - suspension - expulsion - Russia

\section{Introduction: How to Push Back Against the Pushback?}

In recent years, the regional human rights regimes in Europe, the Americas, and Africa have been faced with an unprecedented amount of criticism, spearheaded by several state parties. ${ }^{1}$ Most importantly, in several instances, this criticism exceeded the ordinary type of state criticism, which has to be expected following a judgement ${ }^{2}$ and is instead aimed at undermining or abolishing the institution as such. ${ }^{3}$ This raises the question of how regional human rights regimes should respond to this so-called backlash. In short, how to push back against the pushback? ${ }^{4}$ This article investigates whether membership sanctions, i.e. sanctions which regulate the participation of state parties in international institutions, are an effective and legitimate instrument to respond to those types of state backlash in the current crisis.

For this reason, this article will critically assess the legal framework of membership sanctions in the European, Inter-American, and African human

1 Karen J. Alter, James T. Gathii and Laurence R. Helfer, 'Backlash against International Courts in West, East and Southern Africa: Causes and Consequences', EJIL 27 (2016), 293-328; Marten Breuer (ed.), Principled Resistance to ECtHR Judgments - A New Paradigm?, (Heidelberg: Springer 2019); Jorge Contesse, 'Resisting the Inter-American Human Rights System', Yale J. Int'l L. 44 (2018), 179-237; Galina A. Nelaeva, Elena A. Khabarova and Natalia V. Sidorova, 'Russia's Relations with the European Court of Human Rights in the Aftermath of the Markin Decision: Debating the "Backlash", Human Rights Review 21 (2020) 93-112.

2 Mikael Rask Madsen, Pola Cebulak and Micha Wiebusch, 'Backlash against International Courts: Explaining the Forms and Patterns of Resistance to International Courts', International Journal of Law in Context 14 (2018), 197-220.

3 Ximena Soley and Silvia Steininger, 'Parting Ways or Lashing Back? Withdrawals, Backlash and the Inter-American Court of Human Rights', International Journal of Law in Context 14 (2018), 237-257.

4 The phrase was coined in December 2018 by UN High Commissioner for Human Rights Michelle Bachelet and repeated in March 2019 by UN Secretary-General António Guterres. 
rights regimes and analyse how they were applied. Naturally, those three regimes differ significantly in their institutional design. In Europe, the protection of human rights is the primary focus of the Council of Europe (CoE) which is why this article does not discuss the European Union. In the CoE, all state parties have joined the human rights regime. However, at the Organisation of American States (OAS) and the African Union (AU), states are part of a larger regional integration framework, which also includes economic and financial sanctions. States thus have to opt-in to the respective human rights treaties, leading to a more fragmented institutional framework. Yet, all three regimes provide for membership sanctions and the challenges they face are surprisingly similar. In particular, they are all confronted with a significant number of state parties that attempt to undermine or abolish the human rights courts and commissions, for instance, by aggressively calling for abandoning them, ${ }^{5}$ blocking their funding, ${ }^{6}$ setting up parallel institutions, ${ }^{7}$ or effectively depriving them of receiving cases. ${ }^{8}$ This is why this article adopts a comparative regional approach to membership sanctions in the European, Inter-American, and African human rights regimes. ${ }^{9}$

Membership sanctions have long been a topic of concern for international institutions. The legal regulation of membership is one of the most fundamental aspects of an international organisation. Deciding on who is in - and who is out - does not only determine the geographical scope of an organisation, but also its substantive aspirations. ${ }^{10}$ It establishes the values of an international organisation and puts the conditions in place for states to participate on equal terms. ${ }^{11}$ For institutionalist scholars, the regulation of membership is 'clearly one of the basic constitutional questions for international organisations', which 'largely determines the nature of an international

5 For instance, in the case of Venezuela, see Declaration 'Chávez considera que CorteIDH no tiene validez', available at $<$ http://www.youtube.com/watch? $v=$ jhLRJOmbTfs $>$.

6 For instance, in the case of Russia, 'Statement of the Ministry of Foreign Affairs of the Russian Federation Concerning the Suspension of Payment of Russia's Contribution to the Council of Europe for 2017', 30 June 2017.

7 For instance, in the case of Venezuela, see Douglass Cassel, 'Regional Human Rights Systems and State Pushback: The Case of the Inter-American Human Rights System’, HRLJ 33 (2013), 1-10.

8 For instance, in the case of Tanzania, see Nicole De Silva, Individual and NGO Access to the African Court on Human and Peoples' Rights: The Latest Blow from Tanzania, EJIL:Talk!, 16 December 2019.

9 Alexandra Huneeus and Mikael Rask Madsen, 'Between Universalism and Regional Law and Politics: A Comparative History of the American, European, and African Human Rights Systems', I CON 16 (2018), 136-160.

10 Alison Duxbury, The Participation of States in International Organisations: The Role of Human Rights and Democracy (Cambridge: Cambridge University Press 2011).

11 Duxbury (n. 10), 5-6. 
agency, the position that it can claim, and the role that it can play in world affairs'. ${ }^{12}$ Hence, membership sanctions can, at least theoretically, play a crucial role in the fight against state backlash. They can be used to punish defiant state parties, deter like-minded state parties, and safeguard institutional functioning in case of a blockade. ${ }^{13}$ Yet, empirical research in political science has demonstrated that putting member sanctions into practice is more complicated. For instance, Inken von Borzyskowski and Felicity Vabulas registered 95 suspended state parties since 1945, which amounts to a significant number. ${ }^{14}$ However, the authors found that international institutions are quite reluctant to impose suspensions for breaches of fundamental values and human rights norms as the institutions opted to apply sanctions in only one out of 19 possible instances. Other empirical studies on the application of membership sanctions highlighted how the design of suspension clauses, in particular procedural requirements and voting thresholds, impedes the likelihood that sanctions are imposed. ${ }^{15}$

In particular for human rights regimes, membership sanctions pose a dilem$\mathrm{ma}$ as the imposition of sanctions de facto punishes the individuals and communities that human rights regimes are bound to protect. Hence, from a strict human rights paradigm, the effect of expulsion for the most vulnerable persons in a state cannot be justified and thus should never be used as a sanctioning tool. Moreover, putting additional pressure on state parties by imposing suspension or threatening expulsion also increases from the risk of state withdrawal, which again deprives victims of human rights abuses recourse to the courts. Nonetheless, all three regional regimes provide for options to suspend or even expel state parties for violations of human rights and democracy, and there is a small but stable number of cases in which they were put into practice. ${ }^{16}$

12 Inis L. Claude, Swords into Plowshares: The Problems and Progress of International Organization (4th edn, London: McGraw-Hill 1984), 95.

13 See also Frederick Cowell, 'Exit Clauses in Regional Human Rights Systems', International Organizations Law Review 15 (2018), 388-410.

14 Inken von Borzyskowski and Felicity Vabulas, 'Credible Commitments? Explaining IGO Suspensions to Sanction Political Backsliding', International Studies Quarterly 63 (2019), 139-152.

15 See for instance, Inken von Borzyskowski and Clara Portela, Piling on: The Rise of Sanctions Cooperation between Regional Organizations, the United States, and the EU, KFG Working Paper Series 70 (2016), 3-31; Cassandra V. Emmons, Regional Organizations as Democracy Enforcers: The Design of Suspension Clauses in the EU, OAS, and AU, PEIO 11th Annual Conference (2017), 1-42; Heidi Hardt and Brendt E. Sasley, When States Break the Rules: Membership Suspension in International Organizations, Annual Convention of the American Political Science Association (2014), 1-24.

16 See, for instance, Kanstantsin Dzehtsiarou and Donal K. Coffey, 'Suspension and Expulsion of Members of the Council of Europe: Difficult Decisions in Troubled Times', ICLQ 68 (2019), 443-476. 
Against this background, this article traces the law and practice of membership sanctions in the three regional human rights regimes to assess how, why, and when membership sanctions are applied vis-à-vis state parties. In the first step, I will elaborate on why and how membership sanctions should be applied in times of state backlash (II.). In the second step, I will first comparatively analyse the available instruments in the European, InterAmerican, and African regimes (III.), before zooming into the case study of Russia and the question of membership sanctions in the CoE (IV). The insights derived by both the comparative analysis and the case study of Russia are then used to answer the research question, namely whether membership sanctions are an effective and legitimate instrument to combat state backlash in the current crisis.

\section{The Role of Membership Sanctions}

The role of membership sanctions has long been a topic of concern to international institutions. While some believe that sanctions serve an important function to safeguard the institution by drawing red lines and deterring other states, others argue that sanctions, which induce states to leave an institutional arrangement, harm institutional authority and prevent the institution from influencing the state's behaviour. ${ }^{17}$ In this section, I will investigate on which options for sanctioning the membership of a state are available to international organisations (1.), before arguing why membership sanctions should be explored as a valuable instrument for regional human rights regimes in times of backlash (2.).

\section{How Sanction? Instruments, Rules, and Veto Points}

The discussion on membership sanctions is as old as the origins of international institutions. Already in the League of Nations, the drafters of the Covenant felt the need to include the possibility of sanctions against states which defy the values and principles of the League in Article 16 (4) of the Covenant:

'Any Member of the League which has violated any covenant of the League may be declared to be no longer a Member of the League by a vote of the Council

17 See Louis B. Sohn, 'Expulsion or Forced Withdrawal from an International Organization', Harv. L. Rev. 77 (1964), 1381-1425. 
concurred in by the Representatives of all the other Members of the League represented thereon.'

Nevertheless, the practical application of the expulsion clause turned out to be cumbersome. States had called for the expulsion of Liberia and Ethiopia in the early 1930 s, however, the Council opted to impose economic sanctions instead. ${ }^{18}$ After all, the League only once decided to expel a state party, namely the USSR in 1939. It argued that the USSR, by attacking Finland, had 'placed itself outside of the League of Nations'. ${ }^{19}$ As the Covenant required a unanimous vote on expulsion, President Costa du Rels decided that the four abstaining votes of Greece, Yugoslavia, Finland, and China would not count towards establishing unanimity. ${ }^{20}$ In contrast to the intent of the original drafters, the Soviet expulsion was motivated by functional, and not moral grounds. ${ }^{21}$ Argentina had first proposed expulsion as a symbolic gesture to safeguard the League's heritage during a time when the institution had already lost the strength required for effective economic or military sanctions. ${ }^{22}$ In retrospect, one might question both the appropriateness and effectiveness of the decision as the expulsion of the USSR took place in the twilight of the League of Nations when many states had already withdrawn voluntarily.

In the course of the history of international institutions, the toolbox of membership sanctions broadened significantly. Besides excluding a state party permanently from the institution, the United Nations (UN) Charter also allows for the option of temporary suspension of rights and privileges in the General Assembly in Article 5:

'A Member of the United Nations against which preventive or enforcement action has been taken by the Security Council may be suspended from the exercise of the rights and privileges of membership by the General Assembly upon the recommendation of the Security Council. The exercise of these rights and privileges may be restored by the Security Council.'

In the UN, decisions on both suspension and expulsion must be taken by the Security Council, which allows in principle more flexibility than the unanimity requirement of the League. Nevertheless, up to date, neither

18 Konstantinos D. Magliveras, Exclusion from Participation in International Organisations: The Law and Practice behind Member States' Expulsion and Suspension of Membership (The Hague: Kluwer Law International 1999), 19-28.

19 Resolution passed by the League of Nations on 14 December 1939. See also, Leo Gross, 'Was the Soviet Union Expelled From the League of Nations?', AJIL 39 (1945), 35-44.

20 Sohn (n. 17), 1389.

21 Sohn (n. 17), 1391.

22 Sohn (n. 17), 1388. 
instrument available in Articles 5 and 6 were ever put into practice. While some states called for the expulsion of Israel, as well as Serbia and Montenegro during the conflict in the former Yugoslavia, and South Africa during the apartheid regime, the members of the Security Council, particularly the United States (US) and the United Kingdom (UK), argued in favour of keeping state parties which acted against the core values of the institution within the 'pressures of civilised international opinion'. ${ }^{23}$

Since then, most international organisations have included the possibility of membership sanctions, which usually take the form of either suspension or expulsion. There is a substantial overlap between measures of suspension and expulsion. Suspension can be defined as an institutional instrument, which either temporarily blocks a state party from exercising its membership rights, or, which only targets particular rights, i. e. the state party loses its right of representation in one specific body of the institution. In cases of expulsion, the state party loses all rights of representation in the institution for an unspecified period. In legal terms, the most obvious differentiation between suspension and expulsion is the mechanism of re-entering the regime: while suspension can be terminated by the institution and the member state regain its rights and privileges, the state needs to undergo an official readmission procedure in case of expulsion. However, due to a wide variety of possible measures, it is more appropriate to conceptualise membership sanctions not in a binary (suspension vs. exclusion), but on a scale. Sanctioning instruments range from softer and limited forms of coercion, such as the temporal suspension of voting rights or the right to nominate a candidate for a high-ranking post, to the ultimate removal of the state from the confines of the institutional order. As they share a common aim, namely 'denying the disobedient the benefits of social cooperation and membership', ${ }^{24}$ Oona Hathaway and Scott Shapiro differentiate between 'internal outcasting' in cases of suspension of voting and participation rights, and 'external outcasting' by which a state party loses the benefits of community membership altogether. ${ }^{25}$ The latter usually takes the form of expulsion.

Yet, the evolution of differentiated membership sanctions regimes poses significant challenges for institutional scholars. On the legal dimension, according to Henry G. Schermers and Niels M. Blokker, two core questions exist. The first one concerns the imposition of sanctions on membership states, 'which have violated obligations other than those contained in the

23 See also Duxbury (n. 10), 110-112.

24 Oona Hathaway and Scott J. Shapiro, 'Outcasting: Enforcement in Domestic and International Law', Yale L. J. 121 (2011), 252-349 (252).

25 Hathaway and Shapiro (n. 24), 305-306. 
constitution of the organisation', while the second asks whether sanctions might be imposed 'which are not provided for in the constitution of the organisation'. ${ }^{26}$ Schermers and Blokker concede that a strict interpretation of the powers of international institutions would result in a negative answer. However, they also argue that there is evidence in the practice of international institutions that specialised agencies have sanctioned the violation of extra-constitutional obligations and imposed sanctions, which have not been expressly provided in the founding documents, e. g. the suspension of voting right via discretionary power. ${ }^{27}$

On the procedural dimension, political scientists have pondered the role of institutional rules for the imposition of sanctions. Crucially, in most institutions, there exists no mandatory or automatic procedure for the initiation of sanctions following a particular state action. The adoption of sanctions, even the debate on imposing them in the first place, lies exclusively in the competence of state parties. This is why formal procedural rules such as the requirement of unanimity pose high thresholds for the actual implementation of sanctions. Supermajority rules for the suspension of state parties, in particular in large international organisations, create 'veto points that prevent remaining member states from accumulating sufficient power to act collectively'.28 Moreover, in complex institutional settings, the imposition of sanctions also raises questions of institutional competence and possible consequences on related organs. Ultimately, '[t]he very effort to impose sanctions, even when it is successful, turns into a major issue, disrupts the work of the organization and generates dissatisfaction and resentment among supporters as well as opponents of the action. In other words, as with military and economic sanctions, the political costs of membership sanctions are high. ${ }^{29}$

Those legal and political considerations influence how state parties are sanctioned in international institutions. It might also explain why sanctions are such a rare occurrence in the lifetime of an international institution, in particular for institutions aimed at protecting human rights. Yet, in the current context of an increasing backlash, human rights regimes are hardpressed to safeguard their continued functioning as well as the normative core of their mandate. This puts the option of membership sanctions back on the menu of possible institutional responses. In the next section, I will

26 Henry G. Schermers and Niels Blokker, International Institutional Law: Unity within Diversity (6th edn, Leiden: Nijhoff 2018), 1453.

27 Schermers and Blokker (n. 26), 1453-1454.

28 von Borzyskowski and Vabulas (n. 14), 149.

29 Abram Chayes and Antonia Handler Chayes, The New Sovereignty: Compliance with International Regulatory Agreements (1st edn, Cambridge, Mass: Harvard University Press 1998), 85. 
elaborate on the potential of a proactive strategy, including the adoption of membership sanctions in times of backlash.

\section{Why Sanction? The Need for Carrots and Sticks in Times of Backlash}

Faced with an unprecedented level of criticism and threats to withdraw, regional human rights regimes are currently undergoing a systemic crisis. Backlashing states are frontally opposing the authority of regional human rights courts and commissions by slandering judges, withholding financial contributions, and refusing to sincerely cooperate in the implementation of judgements. ${ }^{30}$ So how should international institutions react to this behaviour? One can generally distinguish between primarily deferential and primarily proactive strategies. Many scholars and practitioners have favoured granting state parties more deference in the implementation of human rights judgements. ${ }^{31}$ This would include more restrictive interpretation methods while strengthening the principle of subsidiarity and judicial dialogue, and developing better monitoring procedures. Moreover, several reform processes

30 There is an emerging literature on backlash against international courts, see also, Laurence R. Helfer, 'Overlegalizing Human Rights: International Relations Theory and the Commonwealth Caribbean Backlash against Human Rights Regimes', Colum. L. Rev. 102 (2002), 1832-1911; Nico Krisch, The Backlash against International Courts, Verfassungsblog, 16 December 2014; Henry Lovat, 'International Criminal Tribunal Backlash' in: Kevin Jon Heller, Frédéric Mégret, Sarah Nouwen, Jens Ohlin, and Darryl Robinson (eds), The Oxford Handbook of International Criminal Law (Oxford: Oxford University Press 2020); Mikael Rask Madsen, 'Two-Level Politics and the Backlash against International Courts: Evidence from the Politicisation of the European Court of Human Rights', The British Journal of Politics and International Relations 22 (2020), 728-738; Wayne Sandholtz, Yining Bei and Kayla Caldwell, 'Backlash and International Human Rights Courts' in: Alison Brysk and Michael Stohl (eds), Contracting Human Rights: Crisis, Accountability, and Opportunity (Cheltenham: Edward Elgar 2018); Leslie Vinjamuri, 'Human Rights Backlash’ in: Stephen Hopgood, Jack Snyder and Leslie Vinjamuri (eds), Human Rights Futures (Cambridge: Cambridge University Press 2017); Erik Voeten, 'Populism and Backlashes against International Courts', Perspectives on Politics 18 (2020), 407-422.

31 Jorge Contesse, 'The International Authority of the Inter-American Court of Human Rights: A Critique of the Conventionality Control Doctrine', The International Journal of Human Rights 22 (2018), 1168-1191; Shai Dothan, 'Judicial Deference Allows European Consensus to Emerge', Chi. J. Int'l L. 18 (2018), 393-419; Andreas Follesdal, 'Independent Yet Accountable: Stress Test Lessons for the European Court of Human Rights', Maastricht J. Eur. \& Comp L. 24 (2017), 484-510; Madsen, Cebulak and Wiebusch (n. 2). Empirical research confirms the move towards deferential judges, see Øyvind Stiansen and Erik Voeten, 'Backlash and Judicial Restraint: Evidence from the European Court of Human Rights', International Studies Quarterly 64 (2020), 770-784. 
took place to accommodate the critics such as the Interlaken Process at the European Court of Human Rights, ${ }^{32}$ the Strengthening Process of the InterAmerican Commission on Human Rights, ${ }^{33}$ or the 2018 decision of the African Union's Executive Council to review the mandate and working methods of the African Commission. ${ }^{34}$

At first glance, a deferential strategy vis-à-vis backlashing states seems a plausible, efficient, and valuable solution. Yet, I believe that it leaves much to be desired. A deferential strategy might secure the existing status quo of human rights regimes but does neither promote nor defend their underlying values. In particular, in the case of human rights courts and commissions, granting too much deference to defiant state parties carries the risk of effectively undermining the system and hollowing out its normative values just as the backlashing state party had attempted in the first place. Moreover, it is not clear whether granting more deference reduces criticism. The experiences of the European Court of Human Rights (ECtHR) and its increasing reliance on the margin of appreciation, ${ }^{35}$ procedural rationality, ${ }^{36}$ and the doctrine of subsidiarity might even prove otherwise. ${ }^{37}$ It seems that deferential strategies do not succeed in appeasing the most vocal backlashing states such as Rwanda, Tanzania, Russia, and Venezuela. Their actions go beyond principled resistance, ${ }^{38}$ as they target the continued functioning of the respective regional human rights regime through setting up parallel institutions, withholding financial contributions, or effectively depriving the court of cases.

According to the basic principle of 'carrot and stick', instruments enabling reward need to be combined with the possibility of punishment. ${ }^{39}$ Following this reasoning, deferential strategies need to be complemented with a proac-

32 ECtHR, Interlaken Process, available at <https://www.echr.coe.int $>$.

33 IACHR, Strengthening Process, available at $<$ https://www.oas.org $>$.

34 Japhet Biegon, The Rise and Rise of Political Backlash: African Union Executive Council's Decision to Review the Mandate and Working Methods of the African Commission, EJIL:Talk!, 2 August 2018.

35 See Janneke Gerards, 'Margin of Appreciation and Incrementalism in the Case Law of the European Court of Human Rights', HRLR 18 (2018), 495-515.

36 See Thomas Kleinlein, 'Consensus and Contestability: The ECtHR and the Combined Potential of European Consensus and Procedural Rationality Control', EJIL 28 (2017), 871893; Patricia Popelier and Catherine Van De Heyning, 'Subsidiarity Post-Brighton: Procedural Rationality as Answer?', LJIL 30 (2017), 5-23.

37 Mikael Rask Madsen, 'The Challenging Authority of the European Court of Human Rights: From Cold War Legal Diplomacy to the Brighton Declaration and Backlash', Law \& Contemp. Probs 79 (2016), 141-178.

38 See Breuer (n. 2).

39 See also Anne van Aaken and Betül Simsek, 'Rewarding in International Law', AJIL 115 (2021), 195-241. 
tive approach towards critical states to strengthen the resilience of the regional human rights regime. Those proactive strategies include 'soft' and 'hard' instruments. The former consists of strategic outreach policies, such as judicial diplomacy ${ }^{40}$ and communication, ${ }^{41}$ or creating windows of opportunity for supporters to mobilise. ${ }^{42}$ Yet, those soft instruments show their limitations in the case of states which block any cooperation or attempt to undermine the institution. In those most extreme cases, it is time to consider 'hard' proactive instruments such as membership sanctions. In other words, international institutions have to decide whether they prefer to keep a defiant state party in their midst or risk casting it out, either internally by suspensions or externally by expulsions. Yet, by their very nature, international institutions struggle with employing membership sanctions: 'As long as member states are neither dependent on international organizations nor convinced of their indispensability, the organizations cannot effectively impose many sanctions, even if their constitutions would allow them to do so. Actions of an organization which antagonize a member may lead to that member severing its relations with the organization.' 43

Consequently, membership sanctions are not employed in a situation of ordinary criticism and non-compliance. As identified by Abram Chayes and Antonia Handler Chayes, '[w]hen membership sanctions are invoked, it is generally as a political response to issues arising primarily outside the organization, rather than as a method of enforcing compliance with the norms of the basic treaty'. ${ }^{44}$ Membership sanctions as a form of punishment ${ }^{45}$ are thus only employed against forms of extraordinary criticism or egregious action by state parties, which effectively shifts the balance towards taking action even if this increases the threat of state withdrawal or negatively affects the domestic population. Fears of institutional survival and continued institutional functioning increase the likelihood that membership sanctions are applied. For instance, Kanstantsin Dzehtsiarou and Donal K. Coffey recently

40 See Theresa Squatrito, 'Judicial Diplomacy: International Courts and Legitimation', Rev. Int'l Stud. 47 (2021), 64-84.

41 See Julian Dederke, Contestation, Politicization, and the CJEU's Public Relations Toolbox: Judgments of the Court of Justice of the EU in Their Public and Political Context (PhD dissertation, ETH Zürich 2020); Matthias Ecker-Ehrhardt, 'International Organizations 'Going Public'? An Event History Analysis of Public Communication Reforms 1950-2015', International Studies Quarterly 62 (2018), 723-736.

42 Larry Helfer, 'Populism and International Human Rights Institutions: A Survival Guide' in: Gerald Neuman (ed.), Human Rights in a Time of Populism: Challenges and Responses (Cambridge: Cambridge University Press 2020).

43 Schermers and Blokker (n. 26), 1450.

44 Chayes and Handler Chayes (n. 29), 68.

45 See also, Kim Richard Nossal, 'International Sanctions as International Punishment', IO 43 (1989), 301-322. 
analysed the current crisis of the CoE.46 They argued that in the existential dilemma of international organisations, namely whether 'to expel or not to expel', three crucial factors need to be considered: First, the existence of a legal option to expel in the founding documents of an international organisation. Secondly, a situation of crisis in which a state party demonstrated significant and exceptional disregard of statutory aims of the organisation. And thirdly, the possibility of expulsion 'should only [be used] as a matter of last resort and after carefully considering all relevant factors' ${ }^{47}$ Hence, along those lines by Dzehtsiarou and Coffey, I do not argue that membership sanctions should be applied in any situation, against a regular instance of non-compliance, or an ordinary form of criticism. Indeed, it is their exceptional nature that makes them particularly influential and authoritative.

In the current context of the three regional human rights regimes, membership sanctions are not only an available instrument of the institutional toolkit, but the institutions themselves are also more likely to apply them to states which fundamentally violate or endanger the institution. However, that does not mean that the legal and political considerations mentioned before should be thrown out of the window. Due to their institutional nature - the European human rights regime overlaps with the CoE, while only a limited number of states parties in the OAS and AU have signed the respective conventions and submitted to the human rights institutions - the imposition of membership sanctions remains complicated and marred with legal and political challenges. In the next section, I will trace the available sanctioning tools and their practical implementation in the regional human rights regimes.

\section{Membership Sanctions in Regional Human Rights Regimes}

The proliferation of international institutions has resulted in a diversification of the design of sanctions clauses as well as an increasing institutional practice. ${ }^{48}$ This paper adopts a comparative regional approach ${ }^{49}$ to the question of membership sanctions in regional human rights regimes. While the European, Inter-American, and African human rights regimes differ significantly, they share a common history and normative vision, which made them

\footnotetext{
46 Dzehtsiarou and Coffey (n. 16), 446-447.

47 Dzehtsiarou and Coffey (n. 16), 446-447.

48 Schermers and Blokker (n. 26).

49 Huneeus and Rask Madsen (n. 9).
} 
overcome significant geopolitical, systematic, and functional hurdles in the last decades. ${ }^{50}$ Nevertheless, all three human rights regimes currently face an unprecedented institutional crisis. ${ }^{51}$ By adopting a comparative regional approach, I aim to contrast the similarities and differences in the imposition of membership sanctions. Hence, in the following, I will analyse the law and practice of expulsion (1.) and suspension (2.) in all three regimes.

\section{The Law and Practice of Expulsion}

For most institutional scholars, expulsion is considered a 'nuclear option', a measure of last resort and there is considerable uncertainty about which type of state behaviour requires an international institution to take this farreaching measure. Still, expulsion is the most traditional membership sanction in international institutions. Why was the option of expulsion included in the League of Nations? Clarence Wilfred Jenks was adamant that the proper way to deal with covenant-breaking states was not expulsion, but even more rigorous international control..$^{52} \mathrm{He}$ argued that the option of expulsion was included in the League of Nations to evade the possibility 'that a state in breach of covenant might attempt to block systematically all League business by voting against every proposal under consideration'. ${ }^{33}$ Thus, the threat of expulsion did not primarily serve as deterrence or 'red line' for state parties endangering the peace, but to guarantee the survival of the institution. Interestingly, even after expulsion from the League, a state might still be bound to fulfil incurred obligations. Jenks argued that '[c]ertain obligations accepted by states as members of the League may be regarded as remaining in force even in respect of an expelled state, particularly in cases in which such obligations arise under instruments creating institutions the proceedings of which cannot be blocked by the veto of any state'. ${ }^{54}$

In all three regimes, the option of expulsion is under-regulated and has never been put into practice. This is not surprising as, for decades, human rights regimes struggled to expand their geographical scope. Hence, expelling state parties runs counter to the normative and functional impetus to broaden

50 Huneeus and Rask Madsen (n. 9).

51 See Tom Gerald Daly and Micha Wiebusch, 'The African Court on Human and Peoples' Rights: Mapping Resistance against a Young Court', International Journal of Law in Context 14 (2018), 294-313; Dzehtsiarou and Coffey (n. 16); Soley and Steininger (n. 3).

52 C. Wilfred Jenks, 'Expulsion from the League of Nations', BYIL 16 (1935), 155-157 (156).

53 Jenks (n. 52).

54 Jenks (n. 52), 157. 
and unify a common regional space. Human rights regimes rather suffer financial constraints and a situation of permanent critique than deprive thousands of people of accessing institutions fundamental to pursuing their rights. Neither the OAS Charter nor the Constitutive Act of the AU provides for the option of the expulsion of a state party. The European human rights regime is the only one to explicitly include a provision on the expulsion of state parties in Article 8 of the Statute of the CoE:

'Any member of the Council of Europe which has seriously violated Article 3 may be suspended from its rights of representation and requested by the Committee of Ministers to withdraw under Article 7. If such member does not comply with this request, the Committee may decide that it has ceased to be a member of the Council as from such date as the Committee may determine.'

In the European system, a state party that has seriously violated Article 3 may be suspended from its right of representation and requested to withdraw:

'Every member of the Council of Europe must accept the principles of the rule of law and of the enjoyment by all persons within its jurisdiction of human rights and fundamental freedoms, and collaborate sincerely and effectively in the realisation of the aim of the Council as specified in Chapter I.'

This provides two possible grounds for expulsion in the European system. On the one hand, a serious violation of the principles of the rule of law and human rights and fundamental freedoms, on the other the (serious) failure to collaborate sincerely and effectively in the realisation of the aims of the CoE. In principle, the former introduces a substantive 'red line', while the latter focuses on the effective functioning of the institution. However, due to the lack of institutional practice and drafting history, ${ }^{55}$ it remains unclear which behaviour amounts to a serious violation or a lack of sincere cooperation.

The closest the European human rights regime ever came to an actual expulsion was the case of Greece in 1969. Greece had been the first state majority of the party to join the original ten founding state parties of the $\mathrm{CoE}$ in 1949. The drafters of the Treaty of London had questioned whether Greece fulfilled the requirements of membership, however, the British, French, and Irish delegates pushed for a rapid accession, also in light of the strong bilateral ties and the Soviet threat. ${ }^{56}$ After a coup d'état in 1967, the human rights situation in Greece deteriorated rapidly under the military

55 The Minutes of the Conference for the Establishment of a Council of Europe, St. James Palace London (3-5 May 1949) only note that Articles 3, 7, and 8 were adopted without disagreement.

56 See Minutes of the Conference (n. 55), $16 \mathrm{f}$. 
junta. ${ }^{57}$ The coup was immediately criticised by the $\mathrm{CoE}$ with the Consultative Assembly calling upon 'the Greek authorities to restore the constitutional regime and system of parliamentary democracy'. ${ }^{58}$ In particular, the then-European Commission of Human Rights was very active in condemning the regime change and adopted various deadlines for Greece to return to democratic standards. As the human rights situation worsened in 1968, the Scandinavian countries later joined by the Netherlands brought a case before the Commission against Greece under Article 24 of the European Convention on Human Rights (ECHR). ${ }^{59}$ At the same time, in the Parliamentary Assembly (PACE), Rapporteur Max van der Stoel presented several reports on the use of torture used by the regime..$^{60}$ On 30 January 1969, after van der Stoel had presented his third report on the situation in Greece, the Assembly decided in Resolution 547 'that the present Greek regime is in serious violation of the conditions for membership of the CoE, as set out in Article 3 of the Statute' and called upon the Committee of Ministers (CM) to expel Greece. ${ }^{61}$ Consequently, in May 1969, the CM issued an ultimatum; the Greek government would have until December to return to democratic practice. In October, the final 1200-page long report by the European Commission on the human rights situation in Greece was leaked to the European press. It found that the military regime had committed widespread and severe human rights violations and the requirements for derogation were not satisfied. ${ }^{62}$ This massive change in public opinion influenced even expulsionaverse states such as Germany and the $\mathrm{UK}^{63}$ and the vote on the expulsion of Greece was scheduled for the next meeting. However, during the meeting on December 12, the Greek representative declared that Greece had decided to voluntarily withdraw from the organisation. ${ }^{64}$

The Greek case exemplifies the inherent link between expulsion and withdrawal. A backlashing state party, which faces a credible threat of expulsion

57 See also Thomas Buergenthal, 'Proceedings against Greece under The European Convention of Human Rights', AJIL 62 (1968), 441-450.

58 PACE, Order 256 (1967), 'General Policy of the Council of Europe'.

59 Denmark, Norway, and Sweden v. Greece, 'Proceedings in Council of Europe on Obligations of Greece Under European Convention on Human Rights’, ILM 6 (1967), 1065-1067.

60 Peter Leuprecht, 'Max van Der Stoel - a Tireless Defender of Greek Democracy', Security and Human Rights 3 (2011), 183-185.

61 PACE, Resolution 547 (1969) 'Situation in Greece'.

62 James Becket, 'The Greek Case Before the European Human Rights Commission', Human Rights 1 (1970), 91-117.

63 Effie G.H. Pedaliu, 'Human Rights and Foreign Policy: Wilson and the Greek Dictators, 1967-1970', Diplomacy \& Statecraft 18 (2007), 185-214.

64 Withdrawal of Greece from the Council of Europe, Speech by the Foreign Minister of Greece H. E. Mr. Panayotis Pipinelis at the Committee of Ministers of the Council of Europe, 12 December 1969. 
is much more likely to withdraw. By withdrawing, the government can 'save face', reduce significant financial and reputational costs, and spin the narrative in its favour for domestic audiences. This does not mean that a human rights regime should shy away from issuing a threat of expulsion, but it certainly exacerbates the imposition of expulsion as a sanctioning instrument. The state party can simply punishment by withdrawing. This might explain why international institutions gravitate towards suspensions to sanction state behaviour, which will be explained in the following section.

\section{The Law and Practice of Suspension}

Suspensions are the most frequently employed sanctioning instrument today. In principle, the suspension of representation and participation rights offers a gradual, transparent, and accountable sanctioning tool. In a best-case scenario, the suspension process identifies the problematic state action, suggests the changes which need to be undertaken, and gives a clear timeline for the perpetuation of the sanction. In contrast to expulsion, suspensions do not follow an 'all or nothing'-approach. Their punishment is aimed at allowing a defiant state party to change its course and rejoin the institution as a full member with all rights and privileges.

Yet, the biggest obstacle to establishing a unified sanctioning regime lies in its fragmented nature. While sanctioning instruments are provided for in the CoE Statute and the Constitutive Act of the AU, the OAS Statute did originally neither offer the possibility of expulsion nor suspension. Moreover, most instruments, which suspend the participation and representation rights of state parties, are not included in the founding treaties or core human rights conventions but can be found in the procedural frameworks of sub-organs, such as Rule 36 of the Rules of Procedure of the AU Executive Council or Rules 8-10 of the Rules of Procedure of PACE. In other cases, options of suspension were introduced via treaties and conventions added to the original human rights regime. Those instruments evolved historically at particular moments of the human rights regime when a certain level of institutional authority had already been established, but the existing framework was insufficient to tackle major existing problems. In the American and African human rights regimes those concern in particular coup d'états and other unconstitutional changes of government, ${ }^{65}$ which

65 See, for instance, Protocol of Washington, Amendment to the OAS Charter (1992), Lomé Declaration on the Framework for an OAU Response to Unconstitutional Changes of Government (2000), Article 30 of the Constitutive Act of the AU. 
resulted most prominently in the Inter-American Democratic Charter (2001) and the African Charter on Democracy, Elections and Governance (2007).

Regional human rights regimes also allow suspending state parties for lack of financial contribution. This is a long-standing debate in international institutional law. For instance, in the League of Nations, Secretary-General Eric Drummond reported in 1927 that the Covenant contained no specific provision on a special sanction for failure to contribute financially. However, according to the 'general principles of law, persistent failure to pay the obligatory contributions would entitle the other members of a union to treat the defalting (sic!) member as failing to perform his obligations under the agreement establishing the union, and would be a sufficient ground for refusing to continue to treat it as a member of the union' ${ }^{66}$

The financial budget constitutes an Achilles heel for regional human rights regimes. To exercise their functions, they depend on a variety of voluntary and compulsory financial contributions, both by state parties and other international donors. Both the American and European human rights regimes suffered severe financial crises in recent years. ${ }^{67}$ In the European human rights system, Article $9 \mathrm{CoE}$ provides the possibility to suspend the right of representation of a state party, which has failed to fulfil its financial obligation, in both the CM and the PACE:

'The Committee of Ministers may suspend the right of representation on the Committee and on the Consultative Assembly of a member which has failed to fulfil its financial obligation during such period as the obligation remains unfulfilled.'

The decision to suspend a state party lies exclusively at the CM and Article 9 remains silent on the majority required for such a decision. The Rules of Procedure of the CM only specify that a proposal for suspension has to be introduced by at least one representative and the final notification of suspension to the state party must set out the legal and financial consequences of this decision. ${ }^{68}$ It is striking that the CoE introduces the temporal suspension of participation and representation rights not for substantive violations of democracy, human rights, or the rule of law, but for non-payment of financial contributions. A substantive violation of those normative values could result in the suspension of all membership rights, i. e. expulsion, as spelled out in

66 League of Nations, 'Legal Position of States which do not Pay their Contributions to the League, League of Nations Official Journal (1927) Issue 4, Annex 943, 506.

67 See also Ximena Soley, A Response to 'A Financial Crisis or Something More?', Voelkerrechtsblog, 22 June 2016.

68 CM, Rules of Procedure, Art. 26. 
Article $8 \mathrm{CoE}$. In this sense, the suspension is primarily used as a safeguard for institutional survival just as envisioned by the League of Nations, not as a 'red line' for substantive violations.

The option to suspend membership rights due to a lack of financial contribution can also be found in the African human rights system. Article 23 (1) of the Constitutive Act of the AU specifies that 'the Assembly shall determine the appropriate sanctions to be imposed on any Member State that defaults in the payment of its contributions to the budget of the Union in the following manner: denial of the right to speak at meetings, to vote, to present candidates for any position or post within the Union or to benefit from any activity or commitments therefrom'. In contrast to the European and American human rights regimes, Article 23 (2) also lists several political and economic sanctions for lack of cooperation with the decisions of the AU as such. Any state party which 'fails to comply with the decisions and policies of the Union may be subjected to other sanctions, such as the denial of transport and communications links with the other Member States, and other measures of a political and economic nature to be determined by the Assembly'. Article 23 thus creates a bifurcated sanctioning regime by combining the suspension of participation rights such as the right to speak, to vote, or to present candidates, with the possibility of political and economic sanctions. While the latter are not affecting the membership of the state party per se, they provide creative sanctioning tools in case a state party does not comply with the decisions of the AU's human rights institutions.

The AU has developed an extensive practice of sanctioning failure to contribute financially to the budget. ${ }^{69}$ Since the Second Ordinary Session of the Executive Council in 2003, a Sub-Committee on Contributions lists those state parties which did not fulfil their financial obligation and suspends their participation rights. The Sub-Committee also pledges to reach out to sanctioned states to encourage them to honour their financial commitment. The procedure thus combines the suspension of participation rights with the shaming of a state party via the official list and offers diplomatic channels to support the state party. While a clear correlation cannot be proven, the number of state parties under sanction dropped from ten in the first year ${ }^{70}$ to

69 See in more detail, Konstantinos D. Magliveras, The Sanctioning System of the African Union: Part Success, Part Failure?, Revised version of a paper presented at an Expert Roundtable on 'The African Union: The First Ten Years' which was organised by the Institute of Security Studies (2011).

70 Guinea Bissau, Liberia, Niger, Central African Republic, Democratic Republic of Congo, Săo Tomé and Principe, Seychelles, Sierra Leone, Somalia, Union of the Comoros. See AU, Executive Council, 3-6 March 2003, $\$ 4$. iii. 
three states in the most recent report in 2018. ${ }^{71}$ The instrument is thus not only predictable and transparent but seems also to be quite effective. Most importantly, the decision to impose and lift the suspension is taken automatically. While Article 23 leaves in principle no discretion for the imposition of sanctions, the Executive Council has introduced mitigating techniques such as exemption of suspension in case a state party faces domestic political and economic struggles which make it impossible to contribute sufficiently to the budget. ${ }^{72}$ In contrast, the European human rights regime has never suspended a state party for non-payment.

In the Inter-American human rights regime, the original OAS Statute of 1948 did neither provide for expulsion nor suspension of state parties. Both actions run counter to the idea of a regionally united, intra-hemispheric platform for cooperation in economic, social, and political relations. Yet, this platform revealed its limitations in the aftermath of the 1959 Cuban revolution. The Ministers of Foreign Affairs decided at the Punta del Este (Uruguay) meeting in 1962 that as a consequence of repeated acts, the present Government of Cuba has voluntarily placed itself outside the inter-American system'. ${ }^{73}$ Consequently, 'this incompatibility [of a Marxist-Leninist government with the inter-American system] excludes the present Government of Cuba from participation in the inter-American system' ${ }^{74}$ Thus, Cuba technically remained a state party, but it was not allowed to send representatives. This situation continued for more than fifty years, until 3 June 2009, when the still socialist government of Cuba was again invited to join the organisation. ${ }^{75}$ Yet, so far, it has refrained from sending representatives.

The highly critical decision to suspend the Cuban government from participating in all OAS matters, thus de facto expelling Cuba from the organisation, demonstrated the need for clear, legal procedures and benchmarks for deciding on the imposition of membership sanctions in the OAS. In the absence of those procedures, the suspension was used for political instrumentalisation. This lacuna was finally rectified in 1992 when an amendment of the OAS Charter, the Protocol of Washington, was adopted. The newly introduced Article 9 provides for the suspension of the right to participate of

71 Central African Republic, Guinea Bissau and South Sudan. See AU, Executive Council, Decision on the Report of the Ministerial Committee on Scale of Assessment and Contributions, 28-29 June 2018, $\mathbb{3}$.

72 For instance Sierra Leone, see AU, Executive Council, Decision on the Report of the Sub-Committee on Contributions, 4-8 July 2003, $\$ 4$ iv.

73 OAS, Resolutions Adopted at the Eighth Meeting of Consultation of Ministers of Foreign Affairs, Punta del Este, Uruguay, 22-31 January 1962, 'Resolution VI. Exclusion of the Present Government of Cuba From Participation in the Inter-American System'.

74 OAS (n. 73).

75 OAS General Assembly, Resolution 2438, Resolution on Cuba, 3 June 2009. 
a state party in case the democratically constituted government is overthrown by force. ${ }^{76}$ The procedure requires a two-thirds majority in the OAS General Assembly and must be coupled with diplomatic initiatives to re-establish representative democracy:

'A Member of the Organization whose democratically constituted government has been overthrown by force may be suspended from the exercise of the right to participate in the sessions of the General Assembly, the Meeting of Consultation, the Councils of the Organization and the Specialized Conferences as well as in the commissions, working groups and any other bodies established.

a) The power to suspend shall be exercised only when such diplomatic initiatives undertaken by the Organization for the purpose of promoting the restoration of representative democracy in the affected Member State have been unsuccessful;

b) The decision to suspend shall be adopted at a special session of the General Assembly by an affirmative vote of two-thirds of the Member States;

c) The suspension shall take effect immediately following its approval by the General Assembly;

d) The suspension notwithstanding, the Organization shall endeavor to undertake additional diplomatic initiatives to contribute to the re-establishment of representative democracy in the affected Member State;

e) The Member which has been subject to suspension shall continue to fulfill its obligations to the Organization;

f) The General Assembly may lift the suspension by a decision adopted with the approval of two-thirds of the Member States;

g) The powers referred to in this article shall be exercised in accordance with this Charter.'

The first time the American human rights regimes implemented the new suspension procedure occurred in 2009. Following a coup d'état against Honduran President Manuel Zelaya, the country was immediately suspended from its right to participation in the OAS. ${ }^{77}$ The resolution to suspend Honduras was adopted unanimously in the OAS after President Zelaya itself took the stand. ${ }^{78}$ After a deal brokered by Venezuela and Colombia between Zelaya and then-President Porfirio Lobo, which allowed Zelaya to return to the country, Honduras was readmitted in $2011 .{ }^{79}$ The Honduran case clearly shows the importance of a transparent and reliable framework for suspending

76 For the historical precedents of Article 9, see Magliveras (n. 18), 166.

77 OAS General Assembly, 'Suspension on the Right of Honduras to Participate in the Organization of American States', 2 June 2009.

78 See also Douglass Cassel, Honduras: Coup d'Etat in Constitutional Clothing?, ASIL Insights 13 (2009), 1-19.

79 OAS General Assembly, 'Participation of Honduras in the Organization of American States', 1 June 2011. 
a state party that violates normative commitments. The combination of suspension as a punishing tool and the continued political and diplomatic support allowed Honduras to rejoin the OAS as a full member after two years. It thereby demonstrates that suspension does not automatically lead to a complete abandonment of a state party and offers important incentives for a domestic policy change. Similar provisions to sanction coup d'états have also been successfully applied in the African human rights regime. ${ }^{80}$

This comparative analysis demonstrated that membership sanctions are available in all three regimes, yet, both their institutional design as well as geopolitical considerations heavily influenced their practical application. While cases such as Greece or Honduras demonstrate the positive effect of membership sanctions, i. e. the institutional authority was safeguarded and both states were able to fully regain their membership rights in due course, the example of Cuba has shown that sanctions are equally prone to abusive application. Moreover, the analysis revealed that suspensions can only be imposed on two very limited grounds of state behaviour, namely withholding financial contributions and unconstitutional change of government.

\section{Membership Sanctions in Times of Backlash: Sanctio- ning Russia}

The doctrinal and historical analysis raises the question of whether the current legal framework of membership sanctions is sufficient to respond to state backlash. The African human rights system, which offers the most gradual suspension regime for coup d'états and lack of financial contributions, is most acutely threatened by a series of withdrawals of the additional protocol by important state parties such as Rwanda and Tanzania. ${ }^{81}$ While those withdrawals threaten the continued functioning of the African Court on Human and Peoples' Rights (ACtHPR), they are expressions of state sovereignty that do not fall within the scope of sanctioned activities. Hence,

80 See, most recently, Manuel Brunner, Entzug von Mitgliedschaftsrechten zur Implementierung von Demokratie: Die Suspendierung des Sudan durch die Afrikanische Union, Voelkerrechtsblog, 28 August 2019.

81 Nicole De Silva, 'Individual and NGO Access to the African Court on Human and Peoples' Rights: The Latest Blow from Tanzania', EJIL:Talk!, 16.12.2019; Nicole De Silva and Misha Plagis, 'A Court in Crisis: African States' Increasing Resistance to Africa's Human Rights Court', Opinio Juris, 19.5.2020; Appolin Koagne Zouapet, "'Victim of Its Commitment ... You, Passerby, a Tear to the Proclaimed Virtue": Should the Epitaph of the African Court on Human and Peoples' Rights Be Prepared?', EJIL:Talk!, 5.5.2020; Oliver Windridge, 'Under Attack? Under the Radar? Under-Appreciated? All of the Above? A Time of Reckoning for the African Court on Human and Peoples' Rights', Opinio Juris, 7.5.2020). 
any imposition of sanctions would be illegitimate. Similarly, in the InterAmerican system, the OAS has never imposed membership sanctions against Venezuela, even though several states spearheaded by the US called for its suspension under the Inter-American Democratic Charter. ${ }^{82}$ This demonstrates that while the imposition of sanctions against Venezuela would have been legitimate following the massive and systematic violations of human rights, democracy, and the rule of law by the Maduro government, the available options turned out to be ineffective. This suggests that membership sanctions in regional regimes are only of limited use to respond to instances of state backlash against human rights.

However, in the European human rights system, the question of membership sanctions rose to prominence during the conflict with Russia. Russia has long been an outspoken critic of the European human rights regime. The relationship between Russia and the ECtHR is difficult, ${ }^{83}$ characterised by systematic non-compliance and attempts to undermine the authority of the Court which peaked in the 2015 Russian Constitutional Court judgement. ${ }^{84}$ Hence, following the invasion of Crimea in 2014, the CoE struggled to impose membership sanctions. Ultimately, instead of imposing the sanctions provided for in the Charter, the PACE decided to suspend Russia's participation and representation rights via the credential procedure. This decision did not only affect the Russian membership but also jeopardised the European human rights system as a whole as Russia refused to pay its financial contributions as long as its voting rights were not restored.

In the following section, I will first explain how the credential procedure was developed as an instrument of irregular suspension (1.), before tracing how the use of the credential procedure against Russia triggered a massive crisis at the $\operatorname{CoE}$ (2.). Ultimately, the Russian case and the ensuing interinstitutional tensions led to the development of a new institutional sanctioning mechanism at the $\mathrm{CoE}$ (3.).

82 The Inter-American Democratic Charter had been invoked for the first time against Venezuela in 2002 following an attempted coup d'etat to remove President Chavez. However, any application of the Charter at a later date has been denied even though the US stated its willingness to invoke the Charter in 2014 and the National Assembly of Venezuela formally requested OAS Secretary General Almagro to apply the Charter in 2016.

83 Jeffrey Kahn, 'The Relationship between the European Court of Human Rights and the Constitutional Court of the Russian Federation: Conflicting Conceptions of Sovereignty in Strasbourg and St. Petersburg', EJIL 30 (2019), 933-959; Lauri Mälksoo and Wolfgang Benedek (eds), Russia and the European Court of Human Rights: The Strasbourg Effect (1st edn, Cambridge: Cambridge University Press 2017).

84 Lauri Mälksoo, 'Russia's Constitutional Court Defies the European Court of Human Rights: Constitutional Court of the Russian Federation Judgment of 14 July 2015, No 21-П/ 2015’, Eu Const. L. Rev. 12 (2016), 377-395. 


\section{The Credential Procedure as an Instrument of Irregular Suspension}

The practice to sanction states via the credential procedure was developed in the United Nations General Assembly vis-à-vis the South African apartheid regime. According to the Rules of Procedure of the General Assembly, the names of members of the delegation of each Member State have to be submitted to the Secretary-General. ${ }^{85}$ The nine-person Credentials Committee is then tasked with examining the credentials of representatives and report to the Assembly. The Rules of Procedure do not specify which procedural or substantive grounds would qualify for refusing representatives of national delegations, hence, the credential procedure was perceived as a pure formality.

This changed after the attempts to expel South Africa in the Security Council had failed. In contrast to the expulsion procedure, the credentials process was governed by the General Assembly, where the critics of the South African apartheid regime enjoyed much greater support. ${ }^{86}$ From 1970 until 1974, the Assembly had consistently contested the credentials of the delegation, even though they had been confirmed earlier by the Credentials Committee. ${ }^{87}$ Yet, on 30 September 1974, the Committee decided by five votes to reject the credentials of the South African delegation. ${ }^{88}$ The President of the Assembly Abdelaziz Bouteflika later clarified that this decision is tantamount to saying in explicit terms that the General Assembly refuses to allow the delegation of South Africa to participate in its work'. ${ }^{89}$ The rejection of the South African credentials meant that representatives lost the ability to participate in the General Assembly, thus amounting to a de facto suspension of a state party. By sidestepping the regular suspension procedure in Article 5, the General Assembly did overreach its competence. ${ }^{90}$ However, other scholars argued that suspension must be differentiated from the question of representation and there existed an inherent right of the Assembly to

85 UN General Assembly, Rules of Procedure, Rules 27-29.

86 Dan Ciobanu, 'Credentials of Delegations and Representation of Member States at the United Nations', ICLQ 25 (1976), 351-381. See also Magliveras (n. 18), 208-222.

87 See also General Assembly, Resolution 3207, 2248th plenary meeting, 30 September 1974, 'Relationship between the United Nations and South Africa'.

88 UN General Assembly, Credentials Committee, 'Credentials of Representatives to the 29th session of the General Assembly’, A/9779, 29th session, Agenda item 3.

89 UN General Assembly, UN Doc. A/PV. 2281, (1974), 8-9.

90 Eckart Klein, Zur Beschränkung von Mitgliedsrechten in den Vereinten Nationen. Eine Untersuchung zum Südafrika-Beschluss der Generalversammlung vom 12. November 1974, Vereinte Nationen (1975), 51-56. 
exclude South Africa as the decision only affected the representation from a particular regime, not the status of the state party per se. ${ }^{91}$

A similar debate arose recently in the European human rights regime. Both expulsion and suspension fall in the competence of the CM and require a two-thirds majority of all state parties. This imposes a high threshold for the imposition of membership sanctions, which might explain why the CM has never initiated a measure under Articles 8 or 9. However, other institutional organs of the $\mathrm{CoE}$ are not bound by the same obstacles. Accordingly, the PACE developed a practice, which, similar to the suspension of South Africa from the UN General Assembly, relies on the credential process to impose de-facto membership sanctions.

The PACE as the parliamentary body of the CoE is comprised of delegations of national parliaments of all member states. In 2000, the PACE amended its Rules of Procedure and introduced a tripartite credentials procedure for the acceptance of national delegations. ${ }^{92}$ Rule 7 allows the PACE to challenge unratified credentials on procedural grounds. Those generally concern the principles in Rule 6.2, which provide for political and gender balance in the delegations. Examples include, among others, all-male delegations proposed by Ireland and Malta in 2004, ${ }^{93}$ which did not receive their voting rights until female delegates were included. While Rule 7 is generally unproblematic, Rule 8 concerns challenges to unratified credentials based on substantive grounds:

'(1) The unratified credentials of a national delegation as a whole may be challenged on the substantial grounds set out in paragraph 2 by:

a. at least thirty members of the Assembly present in the Chamber, belonging to at least five national delegations, or

b. a report of the Committee on the Honouring of Obligations and Commitments by Member States (Monitoring Committee).

The authors shall state the reasons for the challenge.

(2) The substantive grounds on which credentials may be challenged are:

a. a serious violation of the basic principles of the Council of Europe mentioned in Article 3 of, and the Preamble to the Statute [...]

b. persistent failure to honour obligations and commitments and lack of cooperation in the Assembly's monitoring procedure.'

91 Raymond Suttner, 'Has South Africa Been Illegally Excluded from the United Nations General Assembly?', CILSA 17 (1984), 279-301.

92 See also Paul Evans and Paul Silk (eds), The Parliamentary Assembly: Practice and Procedure (11th edn, Strasbourg: Council of Europe Publishing 2013), 109-116.

93 PACE, Resolution 1360 (2004), 'Contested Credentials of the Parliamentary Delegations of Ireland and Malta'. 
Rule 9 then regulates how previously ratified credentials can be challenged on the same substantive grounds:

'(1) The Assembly may reconsider ratified credentials of a national delegation as a whole in the course of the same ordinary session either:

a. on a motion for a resolution to annul ratification based on the grounds set out in Rule 8, or

b. on the basis of a report by the Monitoring Committee containing a text which recommends that the credentials be reconsidered.

(2) A motion for a resolution to annul ratification shall be tabled by at least fifty representatives or substitutes, belonging to at least two political groups and five national delegations, and be distributed at least two weeks before the opening of a part-session or a meeting of the Standing Committee. The list of signatories may not include more members of a delegation than the number of seats held by that delegation in the Assembly. The motion for a resolution shall state the reasons for it. Once tabled, a motion cannot be withdrawn by its authors and no signature may be withdrawn or added to it. It shall be referred without debate to the appropriate committee for report and to the Committee on Rules of Procedure, Immunities and Institutional Affairs for opinion. It may be referred, if necessary, to other committees for opinion. The committee shall report within twenty-four hours if possible and the Assembly shall consider it as soon as possible. These deadlines do not apply to the Standing Committee.'

According to Rule 10, the credential procedure can result either in the ratification or the non-ratification of the credentials, as well as ratification combined with further sanctions such as 'depriving or suspending the exercise of some of the rights of participation or representation of members of the delegation concerned in the activities of the Assembly and its bodies' ${ }^{94}$ For instance, in April 2000, the credentials of the Russian delegations were ratified, but due to the massive human rights abuses in Chechnya ${ }^{95}$ Russia was deprived of its voting rights from April 2000 until January 2001.96

The outcome of this rather technical credential process has massive implications on the participation of a state party. While it does not preclude the state to participate in the CM, a state whose delegations' credentials were challenged is not able to exercise its right to elect judges and senior personnel, table motions, and address questions to the CM. Even though the examination of credentials has been exercised in this way for the last two decades, its legitimation remains questionable as the PACE developed and regulated this

94 PACE, Rules of Procedure, Rule 10.

95 PACE, Doc. 8701 (2000) 'Credentials of the Delegation of the Russian Federation'.

96 PACE, Resolution 1241 (2001), 'Credentials of the Delegation of the Russian Federation'. 
practice in its Rules of Procedure in the absence of clear authorisation of the Statute of the CoE. This problem recently triggered an extensive debate on the CoE's sanctioning procedures.

\section{The PACE and the Credentials of the Russian Delegation}

Following the Russian annexation of Crimea in March 2014, two motions for a Rule 9 procedure to reconsider on substantive grounds the previously ratified credentials of the Russian delegation were introduced in the PACE. While the Assembly decided not to reconsider the credentials to continue the dialogue with Russia, it decided to suspend the voting rights, the right to be represented in the Assembly's bodies, and the right to participate in election observation missions until the end of $2014 .{ }^{97}$ Moreover, it notified that the 'Assembly reserves the right to annul the credentials of the Russian delegation, if the Russian Federation does not deescalate the situation and reverse the annexation of Crimea. ${ }^{98}$ As Russia did not comply with several PACE resolutions, the aforementioned rights remained suspended in the 2015 session, too. ${ }^{99}$

At the beginning of the 2016 session, Russia failed to resubmit its credentials for examination, a strategy it continued also in the following two years. ${ }^{100}$ The conflict aggravated when the Russian Ministry of Foreign Affairs announced in 2017 that it had 'decided to suspend payment of its contribution to the budget of the Council of Europe for 2017 until full and unconditional restoration of the credentials of the delegation'.101 Russia had been one of the five major contributors of the $\mathrm{CoE}$, hence, this decision caused a severe budget crisis. Since then, Russian officials announced that Russia would only consider rejoining the PACE when the option to challenge credentials on substantive grounds will be removed from the Rules of Procedure.

The Russian threat loomed large over the discussion of a reform of the PACE. In 2017, an Ad hoc Committee on the role and mission of the Assembly was formed to, inter alia, harmonise the rules governing the

97 PACE, Resolution 1990 (2014), 'Reconsideration on Substantive Grounds of the Previously Ratified Credentials of the Russian Delegation'.

98 PACE (n. 97), $\ 16$.

99 PACE, Resolution 2034 (2015) 'Challenge, on Substantive Grounds, of the Still Unratified Credentials of the Delegation of the Russian Federation'.

100 PACE, Statement by the Secretary General of the Parliamentary Assembly, 19.10.2018.

101 Statement of the Ministry of Foreign Affairs of the Russian Federation concerning the Suspension of Payment of Russia's Contribution to the Council of Europe for 2017. 
participation and representation of state parties in the PACE and the CM. ${ }^{102}$ The credential procedure turned out to be the main point of contention. On 21 September 2018, Rapporteur Petra de Sutter presented a first report on 'Strengthening the decision-making process of the Parliamentary Assembly concerning credentials and voting'. ${ }^{103}$ The report proposed to keep the credentials procedure as a sanctioning tool but to require a higher quorum for initiating and rejecting credentials, as well as to exempt the right to elect judges and senior $\mathrm{CoE}$ personnel from the sanction procedure. When state parties such as Ukraine, Georgia, and the Baltic States were very vocal in criticising those amendments and calling them out as appeasement of Russia, the proposal was moved back to the Committee. ${ }^{104}$

Ultimately, rising inter-institutional tensions between the $\mathrm{CM}$ and the PACE peaked at the ministerial meeting in May 2019 when a compromise was brokered between Russia and the CoE. The CM agreed to amend the suspension process by introducing a new 'joint reaction procedure' in case a state party violates its statutory obligations, which will be discussed in the following section. Moreover, the CM pointed out that due to the upcoming election of the Secretary-General and several ECtHR judges it would 'welcome that delegations of all member States take part in the next June partSession of the Parliamentary Assembly'. ${ }^{105}$ This required, on the one hand, that Russia would submit its credentials, and on the other, that no challenge of credentials or suspension of voting rights would be introduced vis-à-vis Russia by the PACE. One month later, during the summer session of the PACE, the Assembly agreed to amend Rule 10 of its Rules of Procedure by exempting the right to vote, to speak, and to be represented from suspension. ${ }^{106}$ In turn, Russia submitted its credentials and was accepted with full membership rights despite challenges by Ukrainian and Georgian representatives on substantive and procedural grounds. ${ }^{107}$

102 PACE, 'An Ad hoc Committee on the Role and Mission of the Assembly', 12 December 2017.

103 PACE, Doc. 14621 (2018), Report by Petra de Sutter, 'Strengthening the Decisionmaking Process of the Parliamentary Assembly concerning Credentials and Voting'.

104 For a discussion on this report, see also Andrew Drzemczewski and Kanstantsin Dzehtsiarou, Painful Relations between the Council of Europe and Russia, EJIL:Talk!, 28 September 2018; Lize R. Glas, The Assembly's Appeasement towards Russia, Strasbourg Observers, 27 September 2018; Silvia Steininger, Managing the Backlash?: The PACE and the Question of Participation Rights for Russia, Verfassungsblog, 9 October 2018.

105 CM, 129th Session of the Committee of Ministers, Helsinki, 17 May 2019.

106 PACE, Resolution 2287 (2019) 'Strengthening the Decision-making process of the Parliamentary Assembly concerning Credentials and Voting'.

107 For a critical analysis of this development, see Lize R. Glas, Russia Left, Threatened and Won: Its Return to the Assembly without Sanctions, Strasbourg Observers, 2 July 2019. 
The use of the credential process as a sanctioning tool might constitute an effective, but certainly not fully legitimate means of punishment. In the absence of clear legal authorisation, the PACE developed an extensive practice of challenging the credentials of national delegations. While this was accepted in previous decades, the Russian case highlights its precarious footing in the inter-institutional framework. A report by the CoE's Directorate of Legal Advice and Public International Law clarified that the PACE is well in its right to impose restrictions on participation and voting rights as long as they are confined to internal PACE activities, such as election observation missions or participation in Assembly bodies. However, the complete suspension of membership rights by unilateral PACE action contravenes the prerogatives of the CM. Excluding state parties from essential institutional activities such as the election of judges cannot be justified by implied powers or principles of state responsibility. ${ }^{108}$ This was reaffirmed by the Venice Commission, which highlighted in a 2019 report that while the PACE has an obligation not to recognise annexed territories, this 'does not necessarily entail the obligation to deny credentials to the whole delegation of an annexing State. Other options are possible. The Parliamentary Assembly might consider increasing the range of such options for the future.' ${ }^{\text {'109 }}$

The inter-institutional conflict revealed the futility of the existing sanctioning regime. Since the Crimean crisis, the CoE was hard-pressed to sanction the blatant disregard of European values, but the CM was not willing to take swift action, e. g. to suspend the right of representation following a violation of Article $3 \mathrm{CoE}$ Statute. The Russian case thus stressed the need for an accountable, transparent, and non-politicised suspension procedure, which can punish the violation of fundamental norms and values of the $\mathrm{CoE}$ in line with the Statute. 110 This led to the evolution of the 'complementary joint procedure' in 2019.111

108 Council of Europe, Directorate of Legal Advice and Public International Law, 'Role and Responsibilities of the Council of Europe's statutory organs with special emphasis on the limitation of membership rights', 28 September 2018 (on file with the author).

109 Venice Commission, Opinion No. 955 (2019) 'The compliance with Council of Europe and other international standards of the inclusion of a not internationally recognized territory into a nationwide constituency for parliamentary elections', para. 57.

110 PACE, Resolution 2277 (2019) 'Role and Mission of the Parliamentary Assembly: Main Challenges for the Future', para. 15.

111 The following sub-section was previously published in Silvia Steininger, An Internal Safety Net for the Council of Europe?, Verfassungsblog, 28 December 2019. 


\section{The Development of the Complementary Joint Procedure (2019)}

The development of a new institutional mechanism for better coordination of membership sanctions was fast-tracked at the CoE. In the Helsinki meeting of the CM in May 2019, both the CM and the PACE emphasised:

'the urgent need to develop synergies and provide for co-ordinated action by the two statutory organs, in recognition of their respective mandates, in order to strengthen the Organisation's ability to react more effectively in situations where a member State violates its statutory obligations or does not respect the standards, fundamental principles and values upheld by the Council of Europe."112

The design of such a new, integrated, and coordinated sanctioning instrument became a core aim of the French CoE presidency, ${ }^{113}$ the first draft proposals were published in December 2019, and the resolution was ultimately adopted by PACE in January 2020. Interestingly, both the CM and the PACE reframed the procedure as a form of avoiding membership sanctions:

'the primary aim of the complementary joint procedure is to bring a member State, through constructive dialogue and co-operation, into compliance with the obligations and principles of the Organisation, and avoid imposing sanctions.'114

The resolution emphasised that the new joint procedure should not replace, but complement existing instruments by providing a concerted 'credible, predictable, reactive, and reversible procedure'. Crucially, it remains silent on the use of the credential procedure by the PACE as well as the possibility of suspending the right of representation in the CM under Article $9 \mathrm{CoE}$ Statute. Instead, the resolution repeatedly highlights that the new procedure could result in expulsion under Article 8, following a violation of Article $3 \mathrm{CoE}$ Statute. Hence, it is supposed to facilitate a possible expulsion, which has never taken place in the CoE, and not interfere with the existing options for suspension.

The joint procedure is characterised by an intricate back and forth between several institutional actors. Most importantly, the new procedure can be initiated by three relevant organs: the CM, the PACE, and the Secretary-

112 CM, 129th Session of the Committee of Ministers, Helsinki, 17 May 2019.

113 PACE, 'Emmanuel Macron: "The Council of Europe is the place where the divisions on our continent can be healed"', 1 October 2019.

114 PACE, Resolution 2319 (2020) 'Complementary Joint Procedure between the Committee of Ministers and the Parliamentary Assembly in Response to a Serious Violation by a Member State of its Statutory Obligations'. 
General. It should only be implemented in the most serious, exceptional cases such as violations of Article 3 or the Preamble of the Statute of the CoE, hence a high procedural threshold both for the initiation and the final decision is proposed. While a two-thirds majority is required to initiate the procedure in the $\mathrm{CM}$, the PACE proposal requires the highest possible majority of at least one-fifth of the component PACE members belonging to at least three political groups and fifteen national delegations. Following a motion in the PACE, the Committee on Political Affairs and Democracy will be requested to prepare a report, including a draft recommendation. The recommendation then requires a double majority of two-thirds of the votes cast and votes in favour equivalent to at least one-third of the total numbers of Assembly members.

It also provides a timeline for institutional action. In the four weeks following the initiation of the procedure, the President of the Assembly, the Chairperson of the CM, and the Secretary-General will undertake a highlevel mission to the member state in question to discuss the concerns with the relevant authorities. The resulting report will then be debated in the Assembly before the $\mathrm{CM}$ will decide to either terminate the procedure or continue to the second stage, namely the drafting of a Roadmap by the SecretaryGeneral in the course of the next eight weeks. The Roadmap will contain concrete actions with strict time frames for the state party to implement, as well as a list of initiatives and activities proposed by the various $\mathrm{CoE}$ organs. The Roadmap must also be adopted by the PACE and CM, before the implementation of the Roadmap will be coordinated by the Secretary-General. In general, the implementation of the Roadmap should be finalised in nine months. In case the Roadmap does not lead to an improvement, the final decision of a possible expulsion under Article 8 remains at the $\mathrm{CM}$, again requiring a two-thirds majority. However, the PACE will prepare a report to guide the CM's decision-making.

Certainly, the strict guidelines, including concrete procedural clarifications and timelines, both for the relevant CoE organs and the respective state party, reflect the serious commitment of both the $\mathrm{CM}$ and the PACE to ease interinstitutional tensions and impose not only an effective but also legitimate institutional procedure vis-à-vis defiant state parties. However, to implement this ambitious plan, open questions remain: On the one hand, the threshold for a violation of Article 3 remains underspecified. At this point, the complete and glaring absence of the most prominent defender of European values, the ECtHR, is particularly problematic in the procedure. The jurisprudence of the Court is a crucial guideline for the status of democracy, rule of law, and human rights in state parties. In particular, the implementation of general measures requested in the Court's judgements could be a helpful 
benchmark for developing a Roadmap and would vice versa embolden the Court's authority vis-à-vis defiant states. As the new procedure - from initiation to the implementation of the Roadmap - should take place for only twelve months, the ECtHR's expertise would have decreased the organisational resources required at the $\mathrm{CM}$ and the PACE and hopefully ensured a swifter institutional response.

On the other hand, while the new procedure has diversified the options to initiate the procedure, it still requires significant political will by a very high number of state parties. Hence, it is vulnerable to political blockade and diplomatic blackmail, and state parties will probably remain reluctant to initiate such a cost-intensive procedure. To avoid that the new procedure will share the same fate as Article 8 and 9, it would have been prudent to include an automatic trigger for a debate on a possible motion to initiate a procedure at the CM, or an alert to the Secretary General. Here, the ECtHR's jurisprudence could have served as a handy early warning system. Implementing a judicial threshold, which automatically triggers at least a debate on the motion to initiate the joint procedure, for instance, non-compliance with an infringement proceeding under Article 46 para. 4 ECHR ${ }^{115}$ or several Article 18 ECHR judgements ${ }^{116}$ against a state party, could overcome a possible political blockade, and provide necessary clarification on the scope of Article 3.

Ultimately, the Russian voting rights were restored and the first initiation of the complementary joint procedure is still pending. Any proposal to expulse Russia under Article 8 is highly unlikely as strong institutional players such as the German government ${ }^{117}$ as well as Russian civil society ${ }^{118}$ prefer that Russia remains in the CoE. The fear of the Russian withdrawal might also explain why the CM never initiated a suspension procedure for Russia's failure to contribute under Article 9. Hence, while the conflict with Russia triggered the development of an improved sanction mechanism, it was not the absence of a possible sanction but rather the lack of political will,

115 Başak Çall, No Going Nuclear in Strasbourg: The Infringement Decision in Ilgar Mammadov v. Azerbaijan by the European Court of Human Rights, Verfassungsblog, 30 May 2019; Fiona de Londras and Kanstantsin Dzehtsiarou, Mission Impossible? Addressing NonExecution Through Infringement Proceedings in the European Court of Human Rights, ICLQ 66 (2017), 467-490.

116 Başak Çalı, 'Merabishvili v. Georgia: Has the Mountain Given Birth to a Mouse?, Verfassungsblog, 3 December 2017; Corina Heri, Loyalty, Subsidiarity, and Article 18 ECHR: How the ECtHR Deals with Mala Fide Limitations of Rights', The European Convention on Human Rights Law Review 1 (2020), 25-61.

117 See statement by the German Foreign Minister Heiko Maas: 'Russia belongs in the Council of Europe - with all the rights and obligations that entails'.

118 See also Memorandum 'Addressing the crisis in relations between the Council of Europe and Russia: Uphold the values and fulfil the mission to protect rights across all of Europe'. 
which explains the futility of membership sanctions against Russia in the last decade. While the new procedure provides necessary clarification and diversifies the introduction of sanctions, high majority requirements and the opacity concerning the substantive violations leave it vulnerable to political manipulations and blockade. ${ }^{119}$

The conflict between Russia and the PACE is far from over. In its 2021 winter session, the PACE passed a resolution on the modification of its Rules of Procedure to follow-up with the complementary joint procedure ${ }^{120}$ and the credentials of the Russian delegation were again challenged under Rule 8. In its report on the challenge, Rapporteur Stefan Schennach argued against the imposition of sanctions against Russia but criticised several recent developments such as a rushed constitutional amendment, the poisoning of Alexei Navalny, and the authorities' crackdown on civil society. ${ }^{121}$ Interestingly, in his video presentation, Schennach highlighted two 'ultimate red lines', namely failure to cooperate with the $\mathrm{CoE}$, e. g. the refusal by the Russian authorities to let PACE rapporteurs enter the country, and failure to execute judgements of the ECtHR. ${ }^{122}$ In the debate on the report, representatives of the Ukrainian and Baltic states delegations questioned whether dialogue with Russia is still possible in the PACE, while others argued that the joint complementary procedure would be a more fitting instrument to respond to the deterioration of human rights in Russia than a refusal of credentials. ${ }^{123}$ Russian delegates openly threatened that ' $[\mathrm{i}] \mathrm{f}$ a decision is taken not to ratify our credentials then all members of our delegation will be forced to follow the example of 2014 to leave this hall and to stop the dialogue'.124 In the end, just like in 2020, the credentials of the Russian delegations were ratified and the PACE did neither take concrete steps to initiate a joint complementary procedure nor ratify the credentials with additional PACE-internal sanctions under Rule 10.125

119 Marten Breuer, The Struggle of Strasbourg. The Council of Europe's Response to Rule of Law Backsliding and Serious Violations of Fundamental Principles, Verfassungsblog, 3 February 2020.

120 PACE, Resolution 2360 (2021) 'Modification of the Assembly's Rules of Procedure Follow-up to Resolution 2319 (2020) on the Complementary Joint Procedure between the Committee of Ministers and the Parliamentary Assembly in Response to a Serious Violation by a Member State of its Statutory Obligations'.

121 PACE, Doc. 15216 (2021) 'Challenge, on Substantive Grounds, of the Still Unratified Credentials of the Parliamentary Delegation of the Russian Federation'.

122 PACE, 'PACE's Stefan Schennach: Why we Need the Russian Delegation at PACE', 29 January 2021.

123 PACE, 'Debate: Challenge, on Substantive Grounds, of the Still Unratified Credentials of the Parliamentary Delegation of the Russian Federation", 28 January 2021.

124 ibid. (Fundstelle angeben), statement by Petr Tolstoi.

125 Lize R. Glas, They Did it Again: Russia's Continued Presence in the PACE, Strasbourg Observers, 23 February 2021. 


\section{Conclusion: The Limits of Membership Sanctions}

This article started with the intuition that membership sanctions are an important instrument for regional human rights regimes in times of backlash. Membership sanctions are primarily used as a form of punishment. Naturally, in case of expulsion, this punishment is not primarily aimed at changing a state's behaviour, but to penalise past behaviour and prevent future violations. Suspensions, on the other hand, allow a state party to adapt its behaviour without suffering permanent consequences. By imposing a sanction upon a member, the institution has to strike a delicate balance between keeping critical states engaged in the hope that their continued membership provides more control and socialisation, with the need to safeguard their institutional reputation and drawing red lines. Both options naturally come with significant costs for the institution and the state party but also impact the population of a sanctioned state. This dilemma is particularly acute for human rights institutions, and they are consequently more reluctant to impose membership sanctions. However, I argued that membership sanctions are an important prong for a more proactive strategy to combat state backlash. In particular, membership sanctions can be used to punish backlashing state parties, deter like-minded states, and safeguard institutional functioning in case of a blockade.

However, the doctrinal analysis of the law and practice of membership sanctions in the European, Inter-American, and African human rights regimes revealed that the value of membership sanctions is limited. While all three regimes have developed various options to suspend or even expel state parties, their practical application is often problematic and influenced by political considerations. Sanctions can only be applied in exceptional situations, which either require an underdetermined, but very high threshold such as a violation of Article $3 \mathrm{CoE}$ Statute, or only target very specific state actions. For instance, suspensions of participation and representation rights can only be applied in the case of an unconstitutional change of government or lack of financial contribution. Moreover, the Greek case in the $\mathrm{CoE}$ demonstrated that even when an institution is willing to take harsh measures an actual expulsion is difficult to achieve as a state party might rather choose to withdraw voluntarily. Consequently, the existing membership sanctions have only been of limited value to safeguard the three regional human rights regimes. Instead, in this grey zone, irregular suspension practices such as the use of the credential procedure were developed, which have deepened not only the crisis between Russia and the $\mathrm{CoE}$ but also caused tensions internally between the CM and the PACE. 
Nevertheless, this analysis does not mean that membership sanctions are necessarily futile to combat state backlash. While this article highlighted the limits of the existing sanctioning instruments, it also showcased how the current crises in the three regional human rights regimes could be used to establish a political consensus for reforming the sanction procedures, such as in the case of the new complementary joint procedure at the CoE. Against this background, the examples in this article demonstrated that an effective and legitimate sanctioning regime must be transparent, follow clear legal procedures, should allow for sufficient debate with the respective state party, as well as clearly point out the violation and how it might be remedied. The sanction must be proportionate to the violation and should include a clear timeline. In complex institutional frameworks such as in regional human rights regimes, the inclusion of several institutional organs, as well as domestic state and non-state actors in a sanctioning decision, is certainly beneficial. Institutional crises often have the potential to serve as critical junctures for the evolution of institutional practices and I hope that learning from interregional experiences, both in the drafting of the provisions and the actual application, inspires to create more effective and legitimate sanctioning instruments. 